\title{
Effects of Price Transmission and Exchange Rate Elasticities of Three Developing Countries on the World Cotton Trade
}

\author{
Ozcan Ozturk \\ Correspondence: Ozcan Ozturk, Applied Economics, Auburn University, USA. E-mail: ozo0005@auburn.edu. \\ Received: December 4, 2017 \\ doi:10.11114/aef.v5i1.2894 \\ Accepted: December 22, $2017 \quad$ Available online: December 27, 2017 \\ URL: https://doi.org/10.11114/aef.v5i1.2894
}

\begin{abstract}
This paper examines (i) whether the government interventions in the forms of border protection and as price support have weakened the integrations of domestic cotton markets of China, Brazil and Turkey with the world cotton market and (ii) how a weak cointegration of a domestic market with international market affects the world cotton trade. We address the first question by estimating price and exchange rates transmission elasticities using an error correction model and the second question by conducting a partial equilibrium model. Results indicate that the estimated elasticities are significantly smaller than unitary, which suggests that the cointegration is weak and the law of one price (LOP) does not hold. Furthermore, when cointegration is weak, exchange rate movements have lower impact on exports, imports and prices than they do in the case of strong cointegration.
\end{abstract}

Keywords: market integration, price transmission, error correction model, equilibrium displacement model

\section{Introduction}

Over the last two decades, many developing countries have moved towards liberalization of their agricultural markets to better integrate with the world market. When domestic markets are not integrated with the world market, countries do not gain from the trade as much as they could (Liefert and Persaud, 2009). Hence, market integration has important economic welfare implication. An important requirement for market integration is that the transmission (or pass-through) of world price movement to domestic prices should be complete or sufficiently high. Complete pass-through, however, might not take place due to the following factors: i) border protection policies such as import tariffs, import quotas, export bans and export subsidies; ii) price support policies such as input subsidies, and deficiency payments; iii) imperfect competition in the market; iv) transfer costs; v) changes in exchange rates (Rapsomonikis, 2004; Zorya et al., 2014).

Cotton market is one of the highly supported industries among agricultural commodities in the world. Government supports to the cotton sector including direct support to production, border protection, crop insurance subsidies and minimum support price mechanism are estimated to be $\$ 7.2$ billion in 2015-16 (International Cotton Advisory Committee report, ICAC, 2016). As shown in figure 1, the share of production that receives assistance in the form of direct payments and border production on average was 55\% from $1997 / 98$ to $2007 / 08$, which then increased to $83 \%$ in 2008/09. From 2009/10 to $2013 / 14$ the average share receiving support declined to $48 \%$, and then increased to $76 \%$ again during 2014/15 . In 2015/16 the share declined to 71\%.The Chinese cotton market is subject to an intensive government intervention. The Chinese government controls the cotton import volumes and values and applies border protection measures based on quota and sliding scale duties to protect its cotton producers. In addition, China affects prices through reserves of cotton managed by China National Reserve Corporation (CNCRC). When there is a shortage, CNCRC releases cotton to the market from the reserve through auctions, and when there is a surplus it increases the reserves. Furthermore, the government of China gives subsidies to cotton growers for high quality planting seeds. As a result of these interventions, the Chinese domestic prices have exceeded the international cotton prices (ICAC report, 2014).

Brazil is the fourth largest exporter of cotton, and the third largest supporter of its producers. The Brazilian government has a program called the Equalizer Price Paid to the Producers (PEPRO). Under the PEPRO program, the government gives subsidies to producers based on guaranteed prices. PEPRO was also used to compensate farmers for appreciation of the Brazilian Real per US dollar. Moreover, the government also supports cotton producers by giving subsidized credits for production, marketing and investment (ICAC report, 2014). On the other hand, Brazilian cotton production is affected by high pest control, labor, fertilizer and transportation costs as well as weak infrastructure of rails, highways 
and ports (ICAC report, 2009).

Turkey is the second largest importer of cotton, and the fourth largest supporter of cotton after China, USA and Brazil. The government of Turkey supports producers by paying premium per kilogram of seed. The government also supports farmers by giving low-cost loans through cooperatives (ICAC report, 2014).

All these policies raise questions as to: (i) whether these interventions have distorted the cointegration of the domestic cotton markets of China, Brazil and Turkey with the world cotton market. If they have, then (ii) how does a weak cointegration affect the world cotton trade? The first question can be addressed by estimating exchange rates and price transmission elasticities and the second question can be analyzed within a partial equilibrium framework.

The purpose of this article is to estimate exchange rate and price transmission elasticities for three developing countries (China, Turkey and Brazil) and measure their impact on the world cotton market.

\subsection{Price Transmission, Market Integration and the Law of One Price (LOP)}

The concept of price transmission has been analyzed within the context of the law of one price (inter alia Asche et al., 2012 and Olsen et al.,2015), or within the context of market integration (inter alia Mundlak and Larson, 1992; Quiroz and Soto, 1996; Abdulai,2000; Sharma, 2002; Baquedano et al.,2011;Minot, 2011; Sekhar, 2012 and Baquedano,2014) or reform policy evaluation following the implementation of structural adjustment programs (Baffes and Gardner, 2003; Rapsomonikis, 2004). Another set of research analyzes vertical price transmission along the supply chain from the consumer to the producer (inter alia Wohlgenant, 1985; Kinnucan and Forker, 1987; Goodwin and Holt, 1999; von Cramon-Taubadel, 1999; Vavra and Goodwin, 2005 and Brosig 2011; Bor et al. 2013).

Market integration and LOP requires that once prices are converted to a common currency, the price of a commodity should be the same in different countries.

For a net importing country, Law of One Price (LOP) implies that import price equals world price plus per-unit transaction cost. With this in mind, let prices in the initial equilibrium be defined as follows

$$
P_{m}=P_{w}+T
$$

Where $P_{m}$ is the import price in US dollar $P_{w}$ is the world price in US dollar and T is per-unit transportation cost. On the other hand, import price in local currency is expressed as follows:

$$
\tilde{P}_{m}=P_{m} \cdot e
$$

where $\tilde{P}_{m}$ is the local currency price of imports, $e=L C U / U S D$ is the exchange rate (Local Currency Unit divided by U.S. Dollar). Expressing equations (1) and (2) in proportionate change form yields

$$
\begin{aligned}
& P_{m}^{*}=(1-\tau) P_{w}^{*}+\tau T^{*} \quad \text { where } \quad 0<\tau=\frac{T}{P_{m}}<1 \\
& \tilde{P}_{m}^{*}=P_{m}^{*}+e^{*} .
\end{aligned}
$$

The effect of changes in the world price and exchange rate on local currency price can be found by substituting (1') into $\left(2^{\prime}\right)$ :

$$
\tilde{P}_{m}^{*}=(1-\tau) P_{w}^{*}+\tau T^{*}+e^{*}
$$

Since transportation cost data is not available, dropping $\tau T^{*}$ from equation (3) yields

$$
\tilde{P}_{m}^{*}=(1-\tau) P_{w}^{*}+e^{*}
$$

Expressing equation (4) in the regression form :

$$
\ln \tilde{P}_{i}^{*}=c+a_{i} \ln P_{w}^{*}+b_{i} \ln E_{i}^{*}
$$

Where $i=$ Brazil, China and Turkey

LOP is tested with the null hypotheses that exchange rate pass-through is complete, i.e., the exchange rate elasticity $\tilde{P}_{m}^{*} / e^{*}$ is 1 (or $b=1$ ) and world price pass through is complete i.e., price transmission elasticity $\tilde{P}_{m}^{*} / P_{w}^{*}$ is 1 (or $a=1$ ).

In the next section we estimate equation (5) and in section three we analyze the impact of estimated elasticities in a partial equilibrium model. Then we conclude.

\section{Estimation}

\subsection{Model and Data}

The relationship between domestic price, world price and exchange rate can be expressed as follows:

$$
P_{t}^{d}=c+a P_{t}^{w}+b e_{t}+u_{t}
$$


where $P_{t}^{d}, P_{t}^{w}$ and $e_{t}$ denote domestic cotton price and world price of cotton and exchange rates in logarithmic forms, respectively. $c, a$ and $b$ are parameters to be estimated and $u_{t}$ denotes the error term.

As an initial step, we perform Augmented Dickey-Fuller (ADF) test to determine whether the series are stationary or not. If prices are stationary, OLS analysis can be used. If not, cointegration analysis is the appropriate econometric method. As shown in table 1, prices are non-stationary in level, but stationary in first difference, I (1). Hence, cointegration analysis is the appropriate method to infer the long-run relationship between nonstationary time series. For cointegration analysis, we perform Engle and Granger (1987) cointegration test by estimating equation (5') below and testing whether the residuals $(\hat{u})$ are stationary. If the residuals are stationary, then it is said that the two price series are cointegrated. That is, there is a long-run equilibrium relationship between domestic prices and the world price (i.e. there is comovement between prices and domestic prices follow world price signals). Since cointegration is present, the next step $^{1}$ is to run an Error Correction Model (ECM) to estimate the price transmission and exchange rate elasticities for the short and the long run and the speed of adjustment to a new equilibrium following a shock.

To derive ECM, two steps are required (i) estimating equation (5') and (ii) inserting the estimated residuals in equation (6) to correct the deviation from the equilibrium in the last period.

$$
\Delta p_{i t}^{d}=c+\sum_{j=0}^{n} \beta_{j} \Delta P_{t-j}^{w}+\sum_{j=0}^{n} \rho_{j} \Delta e_{t-j}+\delta \underbrace{\left(p_{t-1}^{d}-a p_{t-1}^{w}-b e_{t-1}\right.})+\varepsilon_{t}
$$

Error correction term

Where the Greek letter $\Delta$ is the first difference operator, $\Delta X_{t}=X_{t}-X_{t-1}$ and $p_{t}^{d}$ represents the domestic price of cotton in local currency unit for country i at time t. $p_{t}^{w}$ and $e_{t}$ are world price of cotton in US dollar and exchange rates. All series are in natural logarithmic form.

Equation (6) suggests that changes in domestic cotton prices stem from three sources: changes in world price, changes in exchange rates and changes in error correction term. Equation (6) may contain more lags of changes in domestic prices, world prices and exchange rates, which are decided using Akaika Information Criateria (AIC).

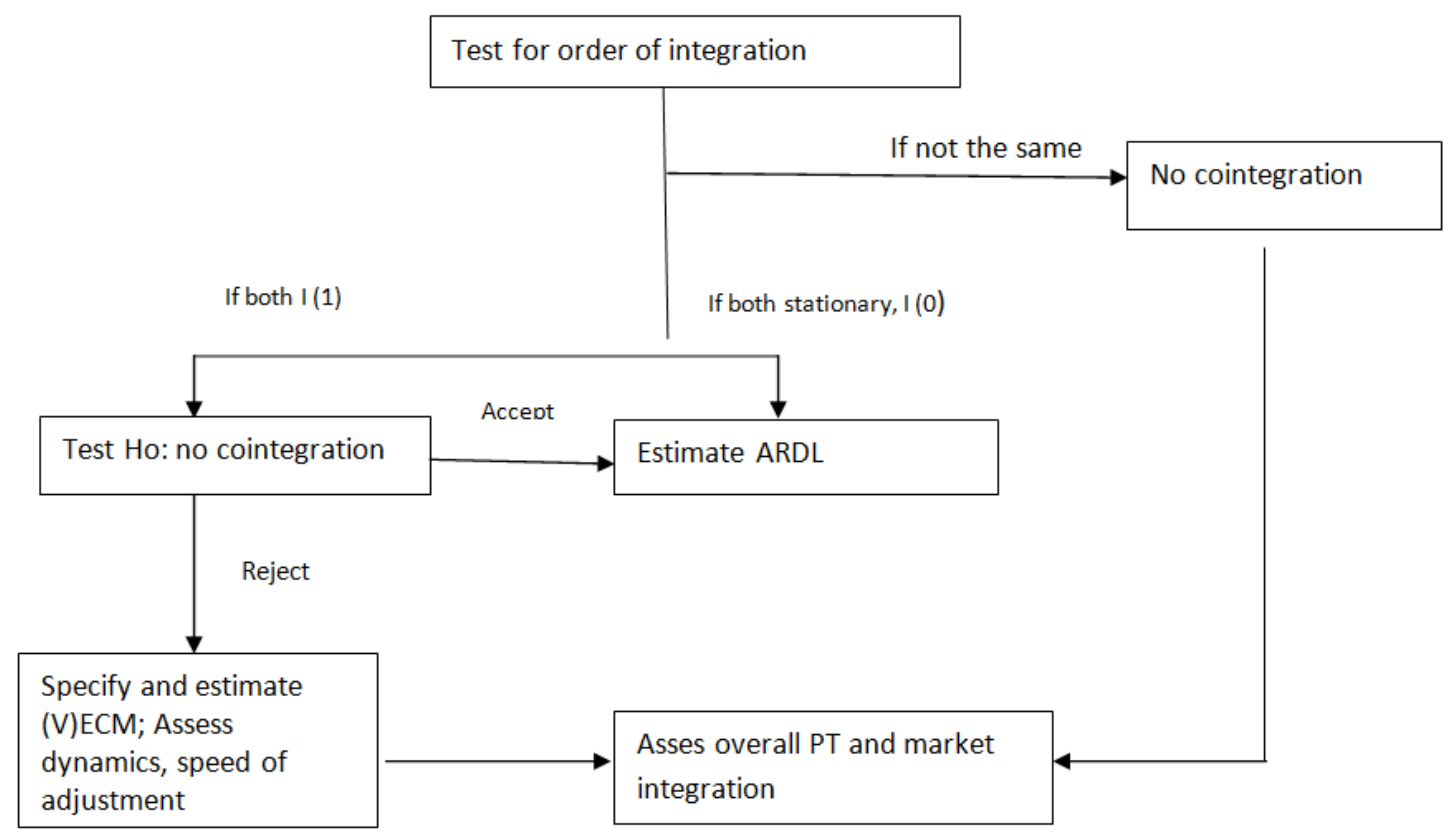

Figure 1. Conceptual framework for assessing price transmission and market integration

Source : Greb at al.(2016) and Rapsomanikis et al.(2003)

The economics interpretation of equation (6) is as follows: The parameters $\beta$ and $\rho$ represent the short run coefficients of world price and exchange rates elasticites ${ }^{2}$ respectively indicating how much of a given shock in the world price of

${ }^{1}$ We follow steps from figure 2 for estimation.
${ }^{2}$ Since they are in logarithmic form, they can be interpreted as price transmission elasticities. 
cotton, and exchange rate will be transmitted to the domestic market prices in the current period (also called initial adjustment term, short-run effect, or contemporaneous effect). $\delta$ is interpreted as coefficient of speed of adjustment to the long run equilibrium showing how much of the past price difference is eliminated in each period (also called error correction term, speed of adjustment or feedback effect). $\alpha$ and $b$ are the long-run coefficients (long run price transmission elasticities). Finally, $\varepsilon_{t}$ is mean zero and iid error term.

We use monthly price and the exchange rate data covering the period from September 2002 to December 2014. For the world price, we use Cotlook A index, which is a proxy for the world price of cotton, obtained from National Cotton Council of America (NCCA). The monthly domestic price data for China is obtained from the Chinese Yearbook of Cotton prepared by the China Cotton information Center (CCIC). The domestic price for Turkey is obtained from the Turkish Statistical Institute (TurkStat) and the Brazilian cotton price data is obtained from the Center for Advanced Studies on Applied Economist (CEPEA/ESALQ). The CEPEA/ESALQ cotton price index is a reference for the Brazilian cotton market and provides the daily prices. We take averages of each month's daily prices to obtain the monthly prices. We deflate all nominal prices using producer price indices that are obtained from the International Monetary Fund for China, Brazil and world prices, and from the Turkish statistical Institution for Turkey. For the exchange rate data, we use monthly average real exchange rates (local currency per \$US) obtained from International Financial Statistics of the International Monetary Fund, Financial Statistics of the Federal Reserve Board.

\subsection{Findings}

Results are presented in table 2. Of the three countries examined, China has the adjusted $\mathrm{R}$ square of 0.30 , which implies that 30 percent of Chinese domestic price variability is explained by world cotton price and exchange rates movements. Similarly, the contemporaneous effect is 0.37 suggesting that a 10 percent increase in the world price leads to a 3.7 percent increase in the Chinese cotton price in the current period. Long run effect is 0.69 and the error correction term in absolute value is 0.19 showing that the world price changes are transmitted to domestic price at a speed of 0.19 .

Turkey's results are close to those of China in terms of the short-run effect and adjusted R square. The adjusted R square of $23 \%$ implies that 23 percent of the variation in domestic price is explained by the world price and exchange rates movements. The short-run effect is 0.33 implying that a 10 percent increase (decrease) in the world price increases (decreases) the domestic price by 3.3 percent in the current period. The long run value is 0.72 which passes through at a 4 percent speed of adjustment.

Brazil has the adjusted $\mathrm{R}$ square of 0.30 , suggesting that 30 percent of variability of domestic price movement reflects movements in the world price and the exchange rates. Brazil also has the highest short-run effect of 0.63 indicating a shock of 10 percent increase in the world market which leads to a 6.3 percent increase in the Brazilian domestic price in the immediate month. The same value for the long run effect is 0.86 . The error correction term for Brazil is the highest of all three countries (0.23) suggesting that it will take shorter time for the Brazilian cotton market to adjust a shock from the world price and the exchange rate movements.

As for the Real Exchange Rate (RER) elasticities $\left(b_{i}\right)$, exchange rate elasticities with 0 values indicate no transmission, no adjustment while 1 indicates a complete transmission and adjustment to a new equilibrium. Our results indicate partial transmission for China, Turkey and Brazil. The estimated exchange rate elasticities for the long run are 0.14, 0.50 and 0.73 which suggest that following a $10 \%$ shock, $1.4 \%, 5 \%$ and $7.3 \%$ increase take place in the domestic prices of China, Turkey and Brazil respectively. Exchange rate shocks adjust in the long run at speeds of 0.14, 0.04 and 0.23.

As discussed earlier the price and the exchange rate elasticities that are significantly smaller than one indicate that there is a weak market cointegration, and that the LOP does not hold. The Wald test results suggest that the estimated price and exchange rate elasticities are significantly different from 1 both in the short run and in the long run.

Considering the extensive government interventions, these results are not surprising. The Chinese government applies border protection measures with a tariff of $40 \%$ to control import volumes. In addition, the cotton reserves managed by CNCRC are used to affect prices in favor of producers by affecting supply and demand (and thus prices). Finally, the government pays direct subsidy to cotton growers (ICAC, 2016).

Nearly $90 \%$ of the producers in Turkey receive a premium of 0.75 TL per kilogram. The Secretariat estimates that total payment to cotton producers in 2015/16 was $\$ 381$ million (ICAC,2016). The government of Brazil provides direct subsidies based on guaranteed prices and subsidized credit for production with an annual average of $\$ 500$ million (ICAC, 2016). These seem to be the underlying causes of the weak cointegration of the domestic markets with the international cotton market.

Since the markets are not cointegrated strongly, the question that comes to mind is whether the weak market integration affect the cotton trade. The next section addresses this question by conducting an Equilibrium Displacement Model $(\mathrm{EDM})$. 


\section{Equilibrium Displacement Model}

As Wohlgenant (2011) defines "EDMs are essentially logarithmic differential equations characterizing comparative statics of a system of equations describing movement from one equilibrium to another resulting from a change in one or more of the parameters (exogenous variables) of the equation system."

EDM uses reduced-form elasticities (also known as total elasticities) to calculate the percentage change in an endogenous variable per one percent change in exogenous variable letting other endogenous variables in the model adjust. Hence, it allows us to calculate the percentage change in the world cotton export and import quantities in respond to changes in price and exchange rate elasticities letting the domestic and world prices adjust.

\subsection{Comparative Statics}

Since we are interested in the world cotton market, we derive import demand and export supply equations from domestic markets of importing and exporting countries. To begin with, consider a country that is net importer of homogenous cotton. Let initial equilibrium of the market be as follows:

$$
\begin{array}{ll}
D=D\left(P_{d}\right) & \text { (Domestic demand) } \\
S=S\left(P_{d}\right) & \text { (Domestic supply) } \\
M=M\left(P_{w}\right) & \text { (Import Supply) } \\
P_{d}=P_{w} \cdot E & \text { (Domestic price) } \\
D=S+M & \text { (Market equilibrium) }
\end{array}
$$

where $\mathrm{E}$ is exchange rate $P_{w}$ is world price. In this model, all exogenous variables except exchange rate are suppressed. Of key interests is effect of exchange rate on import. To derive import demand curve, we first write the model in equilibrium displacement form as follows:

$$
\begin{gathered}
D^{*}=\eta P_{d}^{*} \\
S^{*}=\epsilon P_{d}^{*} \\
M^{*}=\varepsilon P_{w}^{*} \\
P_{d}^{*}=\alpha P_{w}^{*}+b E^{*} \\
D^{*}=k_{d} S^{*}+k_{m} M^{*}
\end{gathered}
$$

Where the asterisked variables indicate relative change $\left(D^{*}=d D / D\right) ; k_{d}=S / D$ is the share of consumption from domestic supply; $k_{m}=M / D$ is the share of consumption from imports; $\eta(<0)$ is domestic demand elasticity, $\epsilon(\geq 0)$ is the domestic supply elasticity, $\varepsilon(>) 0$ is the import supply elasticity.

Substituting $\left(7^{\prime}\right)$ and $\left(8^{\prime}\right)$ into (11') yields import demand curve (12)

$$
\begin{aligned}
\eta P_{d}^{*} & =k_{d} \epsilon P_{d}^{*}+k_{m} M^{*} \\
M^{*} & =\frac{\left(\eta-k_{d} \epsilon\right)}{k_{m}} P_{d}^{*}
\end{aligned}
$$

Domestic consumers respond to domestic price. Substituting (10') into the equation above (to express import demand in world price) yields:

$$
\begin{gathered}
M^{*}=\frac{\left(\eta-k_{d} \epsilon\right)}{k_{m}}\left(\alpha P_{w}^{*}+b E^{*}\right) \\
M^{*}=\frac{a\left(\eta-k_{d} \epsilon\right)}{k_{m}} P_{w}^{*}+\frac{b\left(\eta-k_{d} \epsilon\right)}{k_{m}} E^{*}
\end{gathered}
$$

or

$$
M^{*}=a \eta \dot{\eta} P_{w}^{*}+b \dot{\eta}^{*}
$$

where

$$
\dot{\eta}=\frac{\left(\eta-k_{d} \epsilon\right)}{k_{m}}
$$

is the price elasticity of import demand.

The same analysis can be used for exporting country to derive export supply curve. With the same assumptions, let initial equilibrium be defined as follows: 


$$
\begin{array}{ll}
D=D\left(P_{d}\right) & \text { (Domestic demand) } \\
S=S\left(P_{d}\right) & \text { (Domestic supply) } \\
X=X\left(P_{w}\right) & \text { (Export demand) } \\
P_{d}=P_{w} \cdot E & \text { (Domestic price) } \\
S=D+X & \text { (Market equilibrium) }
\end{array}
$$

Of key interests is exchange rate effect on export. To derive export supply curve, we write the model in equilibrium displacement form as follows:

$$
\begin{aligned}
& D^{*}=\eta P_{d}^{*} \\
& S^{*}=\epsilon P_{d}^{*} \\
& X^{*}=\varepsilon P_{d}^{*} \\
& P_{d}^{*}=\alpha P_{w}^{*}+b E^{*} \\
& S^{*}=k_{s} D^{*}+k_{x} X^{*}
\end{aligned}
$$

Where $k_{S}=D / S$ is the share of production for domestic demand and $k_{x}=X / S$ is the share of export and the parameters denotes the same as importing country case.

Substituting (14') and (15') into (18') and making use of (17') to find export supply curve (19)

$$
\begin{gathered}
\epsilon P_{d}^{*}=k_{s} \eta P_{d}^{*}+k_{x} X^{*} \\
X^{*}=\frac{\left(\epsilon-k_{s} \eta\right)}{k_{x}} P_{d}^{*} \\
X^{*}=\frac{\left(\epsilon-k_{s} \eta\right)}{k_{x}}\left(\alpha P_{w}^{*}+b E^{*}\right) \\
X^{*}=\frac{a\left(\epsilon-k_{s} \eta\right)}{k_{x}} P_{w}^{*}+\frac{b\left(\epsilon-k_{s} \eta\right)}{k_{x}} E^{*}
\end{gathered}
$$

or

$$
X^{*}=a \varepsilon \dot{\varepsilon} P_{w}^{*}+b \dot{\varepsilon} E^{*}
$$

Where

$$
\dot{\varepsilon}=\frac{\left(\epsilon-k_{s} \eta\right)}{k_{x}}
$$

is the price elasticity of export supply. Equations (12 and (19) are of key interest equations which we use to develop the world cotton model in the next section.

\subsection{World Cotton EDM Model}

\section{Structure}

We adopt a two country excess supply and excess demand model similar to one used by Chamber and Just (1979) and Kinnucan and Myrland (2000, 2005).

Net Exporters

$$
\begin{aligned}
& X_{u s}^{*}=\dot{\varepsilon}_{u s} P_{w}^{*} \\
& X_{b r}^{*}=a_{b r} \dot{\varepsilon}_{b r} P_{w}^{*}+b \dot{\varepsilon}_{b r} E_{b r}^{*} \\
& X_{u z}^{*}=\dot{\varepsilon}_{u z} P_{w}^{*} \\
& X_{a u}^{*}=\dot{\varepsilon}_{a u} P_{w}^{*} \\
& X_{i n}^{*}=\dot{\varepsilon}_{i n} P_{w}^{*} \\
& X_{r w}^{*}=\dot{\varepsilon}_{r w} P_{w}^{*}
\end{aligned}
$$

Net importers

$$
\begin{gathered}
M_{c \mathrm{~h}}^{*}=a_{c h} \dot{\eta}_{c h} P_{w}^{*}+b \dot{\eta}_{c \mathrm{~h}} E_{c \mathrm{~h}}^{*} \\
M_{t r}^{*}=a_{t r} \dot{\eta}_{t r} P_{w}^{*}+b \dot{\eta}_{t r} E_{t r}^{*} \\
M_{I d}^{*}=\dot{\eta}_{i d} P_{w}^{*}
\end{gathered}
$$


Price linkages

$$
\begin{aligned}
& M_{b g}^{*}=\dot{\eta}_{b g} P_{w}^{*} \\
& M_{v n}^{*}=\eta_{v n} P_{w}^{*} \\
& M_{w r}^{*}=\eta_{r w} P_{w}^{*}
\end{aligned}
$$

$$
\begin{gathered}
P_{b r}^{*}=a_{b r} P_{w}^{*}+b_{b r} E_{b r}^{*} \\
P_{c \mathrm{~h}}^{*}=a_{c g} P_{w}^{*}+b_{c h} E_{c \mathrm{~h}}^{*} \\
P_{t r}^{*}=a_{t r} P_{w}^{*}+b_{t r} E_{t r}^{*}
\end{gathered}
$$

Market equilibrium

$$
\sum_{i}^{6} k x_{i} X_{i}^{*}=\sum_{j}^{6} k m_{j} M_{J}^{*}
$$

where the asterisk $\left(^{*}\right)$ denotes proportionate change (e.g., $P^{*}=d P / P$ ). $X_{i}^{*}$ represents the world's excess supply for the exporting countries USA, Brazil, India, Australia, Uzbekistan and Rest of the world. $M_{j}^{*}$ represents world's excess demand for the importing countries China, Turkey, Indonesia, Bangladesh, Vietnam and rest of the world. $\eta_{i}^{\prime}(<0)$ is price elasticities of excess demand in the net importing region and $\varepsilon_{i}^{\prime}(>0)$ is price elasticities of excess supply in the net exporting region. $P_{w}^{*}, P_{c h}^{*}, P_{t r}^{*}$ and $P_{b r}^{*}$ represent proportional changes in world price, Chinese price, Turkish price and Brazilian price of cotton. $E_{b r}^{*}, E_{c h}^{*}$ and $E_{t r}^{*}$ represent proportional change in exchange rate of Brazil, China and Turkey. Equations (21)-(36) constitute an equilibrium displacement model (EDM).

The model contains 16 endogenous variables, twelve to represent changes in trade flow $\left(X_{u s}^{*}, X_{b r}^{*}, X_{u z}^{*}, X_{a u}^{*}, X_{i n}^{*}\right.$, $\left.X_{r w}^{*}, M_{c h}^{*}, M_{t r}^{*}, M_{i d}^{*}, M_{b g}^{*}, M_{v n}^{*}, M_{r w}^{*}\right)$ and four to represent changes in price $\left(P_{w}^{*}, P_{c h}^{*}, P_{t r}^{*}, P_{b r}^{*}\right)$.

In this model, all exogenous variables that affect demand and supply are suppressed except three exogenous variables

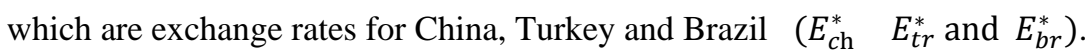

\section{Parameterization}

The model's structural elasticities $\eta$ and $\dot{\varepsilon}$ are derived from the following formulas:

$$
\begin{gathered}
\dot{\eta}=\frac{\left(\eta-k_{d} \epsilon\right)}{k_{m}} \\
\dot{\varepsilon}=\frac{\left(\epsilon-k_{s} \eta\right)}{k_{x}}
\end{gathered}
$$

where $k_{m}$ and $k_{x}$ are import and export share parameters as defined in table 4 . The values of price elasticity of demand $(\eta)$ and price elasticity of supply $(\epsilon)$ are obtained from existing literature. We rely on the estimates of Shepherd (2006) for cotton price elasticity of supply from FAO commodity and trade policy research papers. For price elasticity of demand, we rely on Poonyth et al. (2004) from FAO. (A list of price supply and demand elasticities is provided in table 5).

\section{Reduced form}

We express model's reduced-form (total elasticities) in matrix notation

$$
\mathrm{Y} \Pi=\Gamma Z
$$

Where $\Pi$ is $16 \times 16$ matrix of parameters of model's endogenous variables, $\mathrm{Y}$ is $16 \times 1$ vector of endogenous variables. $\Gamma$ is $16 \times 3$ matrix of parameters corresponding to the model's exogenous variables. Inverse of (19) yields:

$$
\mathrm{Y}=E Z
$$

Where $E=\Pi^{-1} \Gamma$ is a $16 \times 3$ matrix containing the model's full set of total elasticities. We simulate equation (20) two times. in the first, we assume the LOP holds and thus used 1 for price and exchange rate elasticities (i.e. $a=1, b=1$ ). In the second simulation we use the estimated price and exchange rate elasticities from table 2 and compared the two simulations' results.

\subsection{Findings}

In theory, an increase in exchange rate refers to depreciation and a decrease refers to appreciation of local currency if exchange rate is defined as local currency unit per US dollar. If a local currency depreciates, exports increase and imports decrease. If local currency appreciates, imports increase and exports decrease.

For an exporting country, an increase in exchange rate would cause its export to increase. This would lower world price, 
which would cause imports worldwide to increase, and exports of competitors to decrease. Similarly, for an importing country, an increase in exchange rate would cause imports to decrease. This would cause world price to decrease, which would increase imports of competitors and decrease exports worldwide.

Table 3 presents results. Focusing first on price effects, results suggest that an increase in exchange rates of all countries causes world price to decrease. Domestic price effects differ such that an increase in exchange rates of importing countries decreases domestic prices whereas an increase in exchange rate of exporting country increases domestic price of that country.

Looking at the effects of exchange rate changes on trade flow, an isolated $10 \%$ increase in exchange rates of China and Turkey increase cotton exports by $6.4 \%$ worldwide. An isolated $10 \%$ increase in Brazil exchange rate decreases exports by $13 \%$.

Looking at the second part of the table 3, increase in exports worldwide are lower when LOP does not hold. An 10\% isolated increase in exchange rates of China and Turkey increases total exports by $0.9 \%$ and $3.2 \%$ respectively which was $6.4 \%$ when LOP is assumed to hold. Similarly, when LOP is violated, a 10\% increase in Brazil exchange rate decreases world exports by $20.4 \%$ which was $13 \%$ when LOP holds.

Exchange rate changes have negative effects on imports worldwide in response to changes in exchange rates of China and Turkey. Total imports decrease by $6.4 \%$ in response to an isolated $10 \%$ change in exchange rates of China and Turkey, and increase by $13 \%$ in response to a $10 \%$ in Brazil exchange rate. When the LOP does not hold, these figures decrease such that an isolated $10 \%$ increase in exchange rates of China and Turkey decreases total imports by $0.9 \%$ and $3.2 \%$ respectively, (as opposed to $6.4 \%$ when the LOP holds). Similarly, total imports increase by $9.5 \%$ when exchange rate of Brazil increases $10 \%$.

\section{Conclusion}

Our empirical results suggest that the law of one price does not hold for the world cotton market with respect to China, Brazil and Turkey and EDM results show that there are significant impacts of this violation on cotton trade flow and prices.

An increase in exchange rates of China and Turkey cause export of cotton worldwide to increase and imports to decrease. These effects are lower when LOP does not hold. An increase in exchange rate of Brazil, however, causes its exports to increase but exports worldwide to decrease. These effects are lower when LOP is violated. Total imports decrease in response to an increase in exchange rates changes in importing countries. When LOP does not hold total import decreases are lower in response to Chinese and Turkish exchange rate changes. When exchange rates of China and Turkey increase, domestic prices increase, but world price decreases. When LOP does not hold these effects are lower. Brazilian price increase in response to an increase in Brazilian exchange rate, but world price decreases. These effects are lower when LOP does not hold.

\section{References}

Abdulai, A. (2000). Spatial price transmission and asymmetry in the Ghanaian maize market. Journal of Development Studies, 63, 327-349. https://doi.org/10.1016/S0304-3878(00)00115-2

Asche, F., Bennear, L. S., Oglend, A., \& Smith, M. D. (2012). US shrimp market integration. Marine Resource Economics, 27(2),181-192. https://doi.org/10.5950/0738-1360-27.2.181

Baffes, J., \& Gardner, B. (2003). The transmission of world commodity prices to domestic markets under policy reforms in developing countries. Policy Reform , 6(3), 159-180. https://doi.org/10.1080/0951274032000175770

Baquedano, F. G., \& Liefert, W. M. (2014). Market integration and price transmission in consumer markets of developing countries. Food Policy. 104-113. https://doi.org/10.1016/j.foodpol.2013.11.001

Baquedano, F. G., Liefert, W. M., \& Shapouri, S. (2011). World market integration for export and food crops in developing countries: a case study for Mali and Nicaragua. Agricultural Economics, 42(5), 619-630. https://doi.org/10.1111/j.1574-0862.2011.00540.x

Bor, Ö., İsmihan, M., \& Bayaner, A. (2013). Price asymmetry in farm-retail price transmission in the Turkish dairy market. Discussion Paper, Turkish Economic Association.

Brosig, S., Glauben, T., Götz, L., Weitzel, E. B., \& Bayaner, A. (2011c). The Turkish wheat market: spatial price transmission and the impact of transaction costs. Agribusiness, 27(2), 147-161. https://doi.org/10.1002/agr.20257

Chambers, R. G., \& Just, R. E. (1979). A Critique of Exchange Rate Treatment in Agricultural Trade Models. American Journal of Agricultural Economics, 61(2), 249-257. https://doi.org/10.2307/1239729

Engle, F., \& Granger, C. W. J. (1987). Cointegration and error correction: representation,estimation, and testing. 
Econometrica, 55(2), 251-276. https://doi.org/10.2307/1913236

Fackler, P. L., \& Goodwin, B. K. (2001). Handbook of Agricultural Economics: Spatial price analysis. Elsevier, Amsterdam, 971-1024.

Goodwin, A., \& Holt, M. T. (1999). Asymmetric Adjustment and Price Transmission in the U.S. Beef Sector. American Journal of Agricultural Economics, 79, 630-637. https://doi.org/10.2307/1244026

Greb, F., Jamora, N., Mengel, C., Von Cramon, T. S., \& Wurriehausen, N. (2016). Price Transmission from International to Domestic Markets. World Bank, Washington, DC. (c) World Bank. https://openknowledge.worldbank.org/handle/10986/24054 License: CC BY 3.0 IGO

Kinnucan, H. W., \& Forker, O. D. (1987). Asymmetry in Farm-Retail Price Transmission for Major Dairy Products. American Journal of Agricultural Economics, 69,285-292. https://doi.org/10.2307/1242278

Kinnucan, H., \& Myran, O. (2005). Effects of income growth and tariffs on the world salmon market. Applied economics, 1967-7976. https://doi.org/10.1080/00036840500217523

Liefter, W. M., \& Persaud, S. (2009). The Transmission of Exchange Rate Changes to Agricultural Prices Economic research report, United States. Dept. of Agriculture. Economic Research Service) ; no. 76.

Minot, N. (2011). Transmission of world price changes to markets in Sub-Saharan Africa. IFPRI Discussion Paper 01059, International Food Policy Research Institution, Washington, DC.

Mundlak, Y., \& Larson, D. F. (1992). On the transmission of world agricultural. The world bank economic review, 399-422. https://doi.org/10.1093/wber/6.3.399

Poonyth, D, Sarris, A., Sharma, R., \& Shangnan, S. (2004). The impact of domestic and trade policies on the world cotton market. FAO commodity and trade policy research paper.

Quiroz, J., \& Soto, R. (1995). International price signals in agricultural prices: Do governments care? Documento de Investigación No. 88, Programa de Postgrado en Economía ILADES/Georgetown U., Santiago, Chile.

Rapsomanikis, G., Hallam, D., \& Conforti, P. (2003). Market Integration and Price Transmission in Selected Food and Cash Markets of Developing Countries: Review and Applications. In FAO. Commodity Market Review 2003-2004. FAO, Rome.

Secretariat of the International Cotton Advisory Committee. Cotton Fact Sheet Turkey. Available :https://www.icac.org/cotton-economics-and-cotton-statistics/Cotton-Facts (Accessed January 1, 2016).

Secretariat of the International Cotton Advisory Committee. Cotton Fact Sheet Brazil. Available. https://www.icac.org/cotton-economics-and-cotton-statistics/Cotton-Facts. (Accessed January 1, 2016)

Secretariat of the International Cotton Advisory Committee. Production and trade policies affecting the cotton industry. $\begin{array}{llllll}\text { October } 2012 & \text { Washington } & \text { D.C. } & \text { USA. }\end{array}$ at:https://www.icac.org/cotton_info/publications/.../stats.../gm-e_2012.pdf.(Accessed January 1, 2016).

Secretariat of the International Cotton Advisory Committee. Production and trade policies affecting the cotton industry. October 2014.Washington D.C. ASA. Available at: https://www.icac.org/login?url=\%2Fpubdetail.php\%3Fid\%3DP0000102 (Accessed May 27, 2017)

Secretariat of the International Cotton Advisory Committee. Production and trade policies affecting the cotton industry. $\begin{array}{llll}\text { October 2014.Washington } & \text { D.C. ASA. }\end{array}$ https://www.icac.org/login?url=\%2Fpubdetail.php\%3Fid\%3DP0000102.

Sekhar, C. S. C. (2012). Agricultural market integration in India: An analysis of select commodities. Food Policy, 37(3), 309-322. https://doi.org/10.1016/j.foodpol.2012.03.002

Sharma, R. (2002). The transmission of World Price Signals: Concepts, Issues and Some evidence from Asian Cereal Markets. OECD Global Forum on Agriculture, Rome, 2002.

Shepherd, B. (2006). Estimating price elasticities of supply for cotton: a structural time-series approach. Available at: https://mpra.ub.uni-muenchen.de/1252/ [Accessed May 27, 2017].

Vavra, P., \& Goodwin, B. K. (2005). Analysis of Price Transmission Along the Food Chain, OECD Food, Agriculture and Fisheries Papers, No. 3, OECD Publishing, Paris. https://doi.org/10.1787/752335872456

von Cramon, T. S. (1999). The Market for Sugar in Ukraine: Past, Present and Future. In: Siedenberg A., Hoffmann L. (eds) Ukraine at the Crossroads. Physica, Heidelberg. https://doi.org/10.1007/978-3-642-58666-8_15

Wohlgenant, M. K. (1999). Product heterogeneity and the relationship between retail and farm prices. European Review of Agricultural Economics, 26, 219-227. https://doi.org/10.1093/erae/26.2.219 
Wohlgenant, M. K. (2011). Consumer Demand and Welfare in Equilibrium Displacement Models. Available at: http://www.oxfordhandbooks.com/view/10.1093/oxfordhb/9780199569441.001.0001/oxfordhb-9780199569441-e12 [Accessed May 28, 2017].

Zorya, S., von Cramon, T. S., Greb, F., Jamora, N., Mengel, C., \& Würriehausen, N. (2014). Price Transmission from World to Local Grain Markets in Developing Countries: Why It Matters, How It Works, and How It Should Be Enhanced. In Trade Policy and Food Security: Improving Access to Food in Developing Countries in the Wake of High World Prices. Directions in Development - Trade. The World Bank, 65-85. https://doi.org/10.1596/978-1-4648-0305-5_ch3

\section{Appendix}

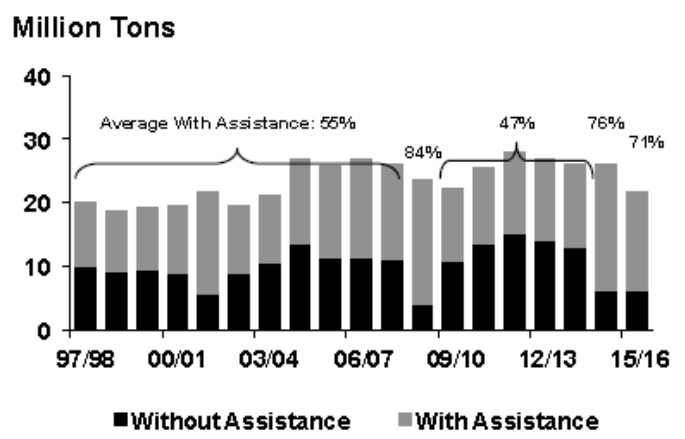

Source: ICAC, 2016

Figure 2. World production under direct assistant.

Table 1. Unit root test for cotton market

\begin{tabular}{llll}
\hline \multicolumn{4}{c}{ Augmented Dicker-Fuller (ADF) test statistic } \\
\hline & At Levels & First Difference \\
\hline World price & -2.08 & $-8.79^{* * *}$ & \\
China & -1.85 & $-12.29^{* * *}$ & \\
Domestic price & & & \\
Exchange rate & 0.50 & -8.92 & \\
Brazil & -2.58 & $-5.93^{* * *}$ & \\
Domestic price & & & \\
Exchange rate & -3.52 & -9.79 & 10 percent \\
Turkey & -2.08 & $-9.73^{* * *}$ & \\
Domestic price & & & -2.58 \\
Exchange rate & -3.27 & $-8.92^{* * *}$ & \\
Critical values & 1 percent & 5 percent \\
ADF & -3.51 & -2.89 & \\
\hline
\end{tabular}

*** unit root null hypothesis is rejected at 1 percent level.

Table 2. Short and long-run world price and exchange rates elasticities

\begin{tabular}{|c|c|c|c|}
\hline & China & Turkey & Brazil \\
\hline \multicolumn{4}{|l|}{ Short Run parameters } \\
\hline \multirow[t]{2}{*}{ World price $(\beta)$} & 0.37 *** & $0.33 * * *$ & $0.64 * * *$ \\
\hline & $(0.08)$ & $(0.05)$ & $(0.07)$ \\
\hline \multirow[t]{2}{*}{ Exchange rate $(\rho)$} & 0.53 & $0.11 * * *$ & $0.29 * * *$ \\
\hline & $(0.84)$ & $(0.07)$ & $(0.13)$ \\
\hline \multirow[t]{2}{*}{ Constant } & $-0.33 * *$ & $-0.27 * *$ & -0.91 \\
\hline & $(0.15)$ & $(0.09)$ & $(0.24)$ \\
\hline \multicolumn{4}{|l|}{ Long Run Parameters } \\
\hline \multirow[t]{2}{*}{ Error Correction term $(\delta)$} & $-0.19 * * *$ & $-0.04 * * *$ & $-0.23 * * *$ \\
\hline & $(0.05)$ & $(0.01)$ & $(0.05)$ \\
\hline \multirow[t]{2}{*}{ World price $(a)$} & $0.69 * * *$ & $0.72 * * *$ & $0.86^{* * *}$ \\
\hline & $(0.04)$ & $(0.02)$ & $(0.05)$ \\
\hline \multirow[t]{2}{*}{ Exchange rate $(b)$} & $0.14 * * *$ & $0.50 * * *$ & $0.73^{* * *}$ \\
\hline & $(0.04)$ & $(0.02)$ & $(0.04)$ \\
\hline $\mathrm{R}^{2}$ & 0.32 & 0.25 & 0.33 \\
\hline $\mathrm{D}-\mathrm{W}$ & 2.29 & 1.88 & 1.81 \\
\hline $\mathrm{N}$ & 147 & 179 & 179 \\
\hline
\end{tabular}

All prices are in U.S. dollars. All prices and exchange rate are in real terms.***, **, * are 1, 5, 10 percent significance levels respectively. D-W is Durbin Watson. $\mathrm{N}$ is number of observations. Numbers in parentheses are standard deviations. 
Table 3. Results with LOP compared with estimated coefficients in the long run.

\begin{tabular}{|c|c|c|c|c|c|c|}
\hline & \multicolumn{3}{|c|}{$\mathrm{a}=1 \mathrm{~b}=1$} & $\mathrm{a}=0.6 \mathrm{~b}=0.14$ & $\mathrm{a}=0.72, \mathrm{~b}=0.50$ & $\mathrm{a}=0.86, \mathrm{~b}=0.73$ \\
\hline Variables & Ech & Etr & Ebr & Ech & Etr & Ebr \\
\hline Xus & 0.19 & 0.19 & -0.65 & 0.03 & 0.10 & -0.49 \\
\hline Xbr & 1.35 & 1.34 & 3.29 & 0.17 & 0.60 & 2.77 \\
\hline Xua & 0.29 & 0.29 & -0.97 & 0.04 & 0.15 & -0.74 \\
\hline Xin & 0.81 & 0.81 & -2.74 & 0.12 & 0.42 & -2.07 \\
\hline Xuz & 3.15 & 3.13 & -10.64 & 0.46 & 1.62 & -8.03 \\
\hline Xrw & 0.53 & 0.52 & -1.78 & 0.08 & 0.27 & -1.35 \\
\hline Total & 0.64 & 0.64 & -1.30 & 0.09 & 0.32 & -2.40 \\
\hline Mch & -0.55 & -0.08 & 0.27 & -0.07 & -0.03 & 0.14 \\
\hline Mtr & -0.62 & -4.25 & 2.11 & -0.09 & -2.14 & 1.64 \\
\hline Mid & -0.52 & -0.52 & 1.77 & -0.08 & -0.27 & 1.34 \\
\hline Mbg & -1.86 & -1.84 & 6.28 & -0.27 & -0.95 & 4.74 \\
\hline Mvn & -3.78 & -3.75 & 12.76 & -0.55 & -1.94 & 9.63 \\
\hline Mrw & 0.00 & 0.00 & 0.01 & 0.00 & 0.00 & 0.01 \\
\hline Total & -0.64 & -0.64 & 1.30 & -0.09 & -0.32 & 0.95 \\
\hline Pch & 1.17 & 0.17 & -0.58 & 1.02 & 0.09 & -0.44 \\
\hline Ptr & 0.17 & 1.17 & -0.58 & 0.02 & 1.09 & -0.44 \\
\hline $\mathrm{Pbr}$ & 0.17 & 0.17 & 0.42 & 0.02 & 0.09 & 0.56 \\
\hline $\mathrm{Pw}$ & -0.17 & -0.17 & -0.58 & -0.02 & -0.09 & -0.44 \\
\hline
\end{tabular}

Table 4. Domestic export and import share parameters used to compute export supply and demand elasticities.

\begin{tabular}{llr}
\hline item & Definition & Value \\
\hline $\mathrm{k}_{\mathrm{us}}$ & share of US's production exported (=Xus/Sus) & 0.79 \\
$\mathrm{k}_{\mathrm{br}}$ & share of BRAZIL's production exported (=Xbr/Sbr) & 0.56 \\
$\mathrm{k}_{\mathrm{au}}$ & share of AUSTURALIA's production exported Xau/Sau) & 0.97 \\
$\mathrm{k}_{\mathrm{in}}$ & share of INDIA's production exported (=Xin/Sin) & 0.32 \\
$\mathrm{k}_{\mathrm{uz}}$ & share of UZBEKISTAN's productionexported(=Xuz/Suz) \\
$\mathrm{k}_{\mathrm{rs}}$ & share of ROW's production exported (=Xr/Sr) & 0.25 \\
$\mathrm{k}_{\mathrm{ch}}$ & share of CHINA's consumption imported(=Mch/Dch) & 0.33 \\
$\mathrm{k}_{\mathrm{tr}}$ & share of TURKEY's consumption imported(=Mtr/Dtr) & 0.43 \\
$\mathrm{k}_{\mathrm{id}}$ & share of INDONESIA's consumption imported(=Min/Din) \\
$\mathrm{k}_{\mathrm{bs}}$ & share of BANGLADESH's consumption imported(=MbG/Dbg) & 0.42 \\
$\mathrm{k}_{\mathrm{vm}}$ & share of VIETNAM's consumption imported(=Mv/Dv) & 0.99 \\
$\mathrm{k}_{\mathrm{rd}}$ & share of ROW's consumption imported(=Mr/Dr) & 0.95 \\
\hline $\mathrm{Valu}$ & & 0.99 \\
\hline
\end{tabular}

Values are 2011-2012 averages computed from data obtained Food Agricultural organization (FAO)

Table 5. Price supply and demand elasticities used to compute export supply and import demand elasticities.

$\begin{array}{lcc} & \text { Supply } & \text { Demand } \\ \text { USA's elasticity } & 0.80 & -0.60 \\ \text { Brazil's elasticity } & 1.20 & -0.60 \\ \text { Austuralia's elasticity } & 0.80 & -0.60 \\ \text { India's elasticity } & 1.20 & -0.80 \\ \text { Uzbekistan's elasticity } & 0.80 & -0.60 \\ \text { Rest of the world's elasticity } & 0.95 & -0.60 \\ \text { China's elasticity } & 1.20 & -1.00 \\ \text { Turkey's elasticity } & 1.20 & -0.60 \\ \text { Indonesia's elasticity } & 0.80 & -0.60 \\ \text { Bangladesh's elasticity } & 1.20 & -0.60 \\ \text { Vietnam's elasticity } & 1.00 & -0.60 \\ \text { Rest of the world's elasticity } & 0.95 & -0.60\end{array}$

Values for Vietnam and ROWs best guess values are used

\section{Copyrights}

Copyright for this article is retained by the author(s), with first publication rights granted to the journal.

This is an open-access article distributed under the terms and conditions of the Creative Commons Attribution license which permits unrestricted use, distribution, and reproduction in any medium, provided the original work is properly cited. 